\title{
БЛОКУВАННЯ ТВАРИННИЦЬКИХ БУДІВЕЛЬ 3 ВИКОРИСТАННЯМ НЕПРИДАТНИХ ЗЕМЕЛЬ У РОСЛИННИЦТВІ
}

\author{
Варпіховський Р. Л., кандидат с.-г. наук, доцент
}

Вінницьькй національний аграрний університет, м. Вінницяя

DOI: https://doi.org/10.31435/rsglobal_sr/31052019/6491

\section{ARTICLE INFO}

Received 22 March 2019

Accepted 14 May 2019

Published 31 May 2019

\section{KEYWORDS}

animal,

building,

block,

land,

high-rise buildings.

\begin{abstract}
It is established that the construction of large volume buildings on the same site allows you to enter a more effective organization of construction works, which ultimately speeds up commissioning and reduces the costs of skotomesto.

Multi-storey buildings dairy enterprises has a number of advantages that allow you to use the agricultural and traditional lands, reduces in comparison with onepiece construction built-up area of the complex is 2-5 times (depending on height), reduces the length of engineering networks and communications, reducing capital investment for the improvement allows the use of more efficient industrial methods of construction and installation works, reduce construction period, contributes to the comprehensive mechanization and automation of production processes, greatly reduce the surface of the enclosure, improving heat balance of the premises, allowing you to maximize the capacity of load-bearing reinforced concrete structures improve architectural expressiveness of livestock enterprises, gives you the opportunity to build a strong base of construction industry of large cities and industrial centers.

It is established that the planning of enterprises for the production of milk with Zabudova building size $42 \times 81 \mathrm{~m}$ in a three-storey version with the use of the land landscape, with a gradient $12-18 \%$ for 1200 cows provides the cost per head of $20,42 \mathrm{~m} 2$, building area of $8.5 \mathrm{~m} 2$, milk production per primary production 187,5 tonnes annually and per hectare of development 2449 tons of milk at the level of profitability $70,74 \%$.
\end{abstract}

Citation: Varpikhovskyi R. L. (2019) Lock Livestock Buildings Using the Land in Crop Production. Science Review. 4(21). doi: 10.31435/rsglobal_sr/31052019/6491

Copyright: (C) 2019 Varpikhovskyi R. L. This is an open-access article distributed under the terms of the Creative Commons Attribution License (CC BY). The use, distribution or reproduction in other forums is permitted, provided the original author(s) or licensor are credited and that the original publication in this journal is cited, in accordance with accepted academic practice. No use, distribution or reproduction is permitted which does not comply with these terms.

Перспективи розвитку молочного скотарства вимагають пошуку оптимального вирішення забудови тваринницьких підприємств (зокрема, підвищення щільності забудови території, що відводяться під сільськогосподарські підприємства 3 виробництва молока), оскільки поки не завжди вдається виключити для використання сільськогосподарських угідь під будівництво відповідну кількість земельної площі. Тому, особливого значення набуває завдання до мінімуму скорочення вилучення земельних площ, що багато в чому залежатиме від прийнятого типу планування і забудови основних будівель.

У цьому відношенні найбільш ефективним представляються створення генпланів тваринницьких підприємств великої потужності з використанням будівель зблокованих по довжині, по ширині та в декілька поверхів $[1,2]$.

Всі блокування приміщень потребують вибору майданчиків для забудови характерні для того чи іншого виду блокування. Так, блокування будівель за шириною потребує також рівного майданчика, блокування за шириною потребує також рівного майданчика, блокування за шириною - майданчики більше 100 м без суттєвих змін ландшафту. У той же час, 
багатоповерхові тваринницькі будівлі для великої рогатої худоби ускладнюють організацію виробництва, особливо обладнання вигульних майданчиків $[3,5]$.

Актуальним $\epsilon$ те, що у сучасних умовах відродження великих спеціалізованих підприємств 3 виробництва молока не можливе без нових проектних розробок, де буде поєднано технологічні процеси (роздача кормів, доїння, видалення гною, утримання) з об'ємнопланувальними рішеннями, які будуть відповідати нормативній фізіологічній діяльності експлуатації організації корів та генетичним задаткам продуктивності $[4,6]$.

Тому, метою наших досліджень було дослідження різної потужності діючих проектних рішень та розробок варіантів можливості будівництва багатоповерхових підприємств 3 виробництва молока.

Методика досліджень. Розробка проектних рішень потребують детальних досліджень відповідності нормативних даних у проектно-кошторисних документаціях, наукових досліджень, типових, експериментальних, індивідуальних та повторного використання проектів. Виходячи із оптимальних результатів визначаються найбільш ефективні технології та економічні рішення. Тому, для вирішення поставлених меж по зменшенню площі забудови території підприємства 3 виробництва молока та визначення потужності підприємства проведені оцінки ефективності за будовою підприємств:

1. Потужність підприємств з виробництва молока на 400, 800 і 1200 корів.

2. Дослідження різних за розмірами будівлі для корів: $72 \times 60 ; 21 \times 78 ; 21 \times 78 ; 10,5 \times 90$; $21 \mathrm{x} 120 ; 45 \mathrm{x} 114 ; 21 \mathrm{x} 112$ м і запропонована багатоповерхова будівля 42x81 м.

3. Серед варіантів утримання худоби досліджені: безприв'язне боксове, безприв'язне на глибокій підстилці, прив'язне.

4. Досліджено доїння корів у двох варіантах: ДАС- 2 Б і «Ялинка».

5. Застосовані роздачі кормів: мобільна і стаціонарна.

6. Механізація видалення гною: транспортером, дельта-скрепером, самопливом, бульдозером.

7. Визначені кошторис забудови, будівельно-монтажні роботи, площа забудови, затрати праці, виробництво молока, прибуток та рентабельність, окупність капіталовкладень та техніко-економічні показники.

8. Виходячи із отриманих даних розроблений технологічний проект можливого використання для будівництва багатоповерхових будівель для великої рогатої худоби та будівництва на рельєфі місцевості, які не використовуються для вирощування рослинних культур з ухилом 12-18\%. Здійснено технологічне та економічне обгрунтування будівництва підприємств з виробництва молока потужністю 1200 корів і більше.

Результати досліджень. Найбільш поширеними спеціалізованими підприємствами 3 виробництва молока є на 400 і 800 корів. В окремих випадках будують підприємства 3 виробництва молока на 1200, 1600, 2000 і більше. У кожному випадку на стадії проектування виникають складності із вибором майданчиків для їх будівництва. Так, розміщення скотарських підприємств здійснюється відповідно до вимог діючих санітарних і будівельних нормативів, земельного, водного, лісового законодавства та інше.

Після вирішення таких законодавчих актів виникло складне питання після розпаювання землі по виділенню майданчиків для забудови підприємства 3 виробництва молока. На 400 корів необхідно від 2 до 3 га землі, для 800 - від 5 до 8 га, для 1200 - від 8 до 10 га.

Досліджені витрати будівлі з різною кількістю будівель від 1638 (варіант 2) до $5130 \mathrm{~m}^{2}$ (варіант 6), але з різною площею будівель від 1 (варіант 1 і 8) до 4 (варіант 3). Тому загальна площа будівель залежить від кількості будівель їх площі та потужності підприємства. Дослідження показали, що дані фактори вплинули на площу забудови, територію підприємств, показники забудови, які були від 2,18 до 10,42 га.

У двох варіантах передбачено прив'язне утримання корів $(2,4)$, у 6 варіантах безприв'язне боксове і у 1 варіанті - безприв'язне на глибокій підстилці. Доїння корів на установці ДАС-2 Б, застосування тільки в одному варіанті, де потужність підприємства 400 корів, в усіх інших - на «Ялинці».

Роздача кормів у двох варіантах - 1 і 8 стаціонарна, а в інших мобільна. У той же час видалення гною транспортером - один варіант транспортером, три - дельта-скрепером, три самопливом і один бульдозером.

У залежності від потужності підприємства та механізації трудомістких процесів працівників від 25 до 76 чоловік та основних робітників від 18 до 64 чоловік. 
Кошторис будівництва від 5778 до 20724 тис. грн. відповідно і будівельно-монтажних робіт від 4962 до 17682 тис. грн.

Такі загальні дані не можуть дати об’єктивну оцінку кращому варіанту планувальнотехнологічним показникам підприємств 3 виробництва молока. Оцінка вартості капітальних вкладень на одне скотомісце показує ефективність техніко-економічних рішень. Так, дві будівлі розмірами $45 \times 114$ м 3 благоустроєм території потребують витрат на одне скотомісце 17274 грн. (варіант 6), підприємство з виробництва молока на 1200 корів (утримання корів безприв'язнобоксове, доїння «Ялинка», роздача кормів мобільна, видалення гною самопливом).

На 800 корів найкращим варіантом за витратами на одне скотомісце (12742 грн.) є будівля 21х120 м з утриманням безприв'язно на глибокій підстилці, кошторис складає 10194 тис. грн., в тому числі: будівельно-монтажні роботи 7571 тис. грн.

Підприємство на 400 корів у будівлі 72х60 м при боксовому утриманні, доїння на ДАС2 Б, роздача кормів стаціонарними роздатчиками, видалення гною - дельта-скрепером витрачається на одне скотомісце 14445 грн.

Дослідження техніко-економічним показників підприємств 3 виробництва молока на 400 корів наступні: площа забудови $54,5 \mathrm{~m}^{2}$ на одну голову, що найменша серед всіх варіантів на 800 і 1200 корів за виключенням на 1200 корів багатоповерхової будівлі, де у даній забудові 20,42 м $^{2}$ на одну голову.

Встановлена площа будівлі на одну корову у підприємстві на 800 корів з утриманням на глибокій підстилці та на 800 корів 3 прив'язним утриманням по 6,30 м² (табл. 1).

Затрати праці всіх працівників на один центнер молока найменші 0,80 люд.-год (варіант 8). Підприємство на 1200 корів у багатоповерховій будівлі, а найбільші - на 800 корів 3,78 люд.-год. будівлі 21x78 (варіант 2). Затрати праці основних працівників складають на 1 центнер молока - 0,53 люд.-год. (варіант 8). Характерно те, що найбільші затрати праці всіх працівників 3,78 люд.-год.

У варіанті 2, де 4 будівлі На 1 ц молока у варіанті 2 на 800 корів 3 прив'язним утриманням, доїння на доїльній установці «Ялинка», з видаленням гною дельта-скрепером затрати праці складають на 1 основного працівника - 3,19 люд.-год.

Вироблено молока на одного працівника найбільше у 8 варіанті (багатоповерхової будівлі) 125 т і найменше - 52,6 т (2 варіанти), відповідно на одного основного робітника 187,5 т і 62,5 т та на один гектар забудови вироблено молока найбільше у 8 варіанті - 2449 т і найбільше - 519,5 т у третьому варіанті.

За рівнем рентабельності перевагу має підприємство на 1200 корів 8 варіант (70,7\%), наступний варіант 7 (62,6\%) на 1200 корів. Серед підприємств на 800 корів лідером за рівнем рентабельності встановлений 5 варіант $(60,4 \%)$.

Найменший рівень рентабельності виробництва молока отримано у першому варіанті на 400 корів. Окупність капіталовкладень складає в 3,02-6,70 років у залежності від потужності підприємства, технологічні та типу забудови приміщень.

Техніко-економічні показники підприємств 3 виробництва молока свідчать про доцільність застосувати проекти багатоповерхових пташників, свинарників, кролятників, будівель для відгодівлі молодняку великої рогатої худоби. Але необхідні пошуки будівництва багатоповерхових будівель для виробництва молока. Відомі і проектні пропозиції таких будівель в інших країнах для утримання молочних корів. Так, фахівці шведської фірми «Альфа Лаваль», прогнозуючи розвиток молочних комплексів у третьому тисячолітті віддають перевагу п’ятиповерховим будівлям (Т-подібним у плані); фахівці у Німечинні розробили проект тваринницької будівлі баштового типу.

Таблиця 1. Техніко-економічні показники підприємств з виробництва молока

\begin{tabular}{|c|c|c|c|c|c|c|c|c|c|c|}
\hline \multirow{2}{*}{ Показники } & \multicolumn{8}{|c|}{ Потужність підприсмств, корів } \\
\cline { 2 - 10 } & $\mathbf{4 0 0}$ & $\mathbf{8 0 0}$ & $\mathbf{8 0 0}$ & $\mathbf{8 0 0}$ & $\mathbf{8 0 0}$ & $\mathbf{1 2 0 0}$ & $\mathbf{1 2 0 0}$ & $\mathbf{1 2 0 0}$ \\
\cline { 2 - 10 } & $\mathbf{1}$ & $\mathbf{2}$ & $\mathbf{3}$ & $\mathbf{4}$ & $\mathbf{5}$ & $\mathbf{6}$ & $\mathbf{7}$ & $\mathbf{8}$ \\
\hline $\mathbf{1}$ & $\mathbf{2}$ & $\mathbf{3}$ & $\mathbf{4}$ & $\mathbf{5}$ & $\mathbf{6}$ & $\mathbf{7}$ & $\mathbf{8}$ & $\mathbf{9}$ \\
\hline $\begin{array}{c}\text { Площа забудови } \\
\text { на 1 корову, м }\end{array}$ & 54,5 & 76,6 & 95,2 & 60,5 & 86,2 & 86,8 & 69,9 & 20,4 \\
\hline $\begin{array}{l}\text { Площа будівлі на } \\
\text { 1 корову, }\end{array}{ }^{2}$ & 10,8 & 8,2 & 9,1 & 6,3 & 6,3 & 8,5 & 8,5 & 8,5 \\
\hline
\end{tabular}


Продовження таблиці 1.

\begin{tabular}{|l|c|c|c|c|c|c|c|c|}
\hline \multicolumn{1}{|c|}{$\boldsymbol{1}$} & $\mathbf{2}$ & $\mathbf{3}$ & $\mathbf{4}$ & $\mathbf{5}$ & $\mathbf{6}$ & $\mathbf{7}$ & $\mathbf{8}$ & $\mathbf{9}$ \\
\hline $\begin{array}{l}\text { Валове } \\
\text { виробництво } \\
\text { молока, тис. ц }\end{array}$ & 20,0 & 40,0 & 40,0 & 40,0 & 40,0 & 60,0 & 60,0 & 60,0 \\
\hline \multicolumn{7}{|c|}{ Затрати праці, тис. люд.-год. } \\
\hline Всього & 49,8 & 151,4 & 77,7 & 99,6 & 107,6 & 117,5 & 135,9 & 95,6 \\
\hline в т.ч. на 1 ц молока & 2,49 & 3,78 & 1,94 & 2,49 & 2,69 & 0,98 & 1,13 & 0,80 \\
\hline $\begin{array}{l}\text { На основних } \\
\text { робітників }\end{array}$ & 38,8 & 127,5 & 53,8 & 87,6 & 67,7 & 85,6 & 79,7 & 63,7 \\
\hline в т.ч. на 1 ц молока & 1,79 & 3,19 & 1,34 & 2,19 & 1,64 & 0,71 & 0,66 & 0,53 \\
\hline \multicolumn{7}{|c|}{ Виробницто молока, т } \\
\hline На 1 працівника & 80,0 & 52,6 & 102,5 & 80,0 & 74,1 & 101,7 & 88,2 & 125,0 \\
\hline $\begin{array}{l}\text { На 1 основного } \\
\text { робітника }\end{array}$ & 111,1 & 62,5 & 148,1 & 90,9 & 117,6 & 139,5 & 150,0 & 187,5 \\
\hline На 1 га забудови & 917,4 & 652,5 & 519,4 & 826,4 & 579,7 & 575,8 & 715,1 & 2449 \\
\hline $\begin{array}{l}\text { Реалізовано } \\
\text { молока, тис. ц }\end{array}$ & 16,4 & 32,8 & 32,8 & 32,8 & 32,8 & 49,2 & 49,2 & 49,2 \\
\hline $\begin{array}{l}\text { Виручка від } \\
\text { реалізації молока, } \\
\text { тис. грн. }\end{array}$ & 3526 & 7052 & 7052 & 7052 & 7052 & 10578 & 10578 & 10578 \\
\hline $\begin{array}{l}\text { Загальні витрати, } \\
\text { млн. грн. }\end{array}$ & 2,6 & 4,7 & 4,5 & 4,5 & 4,4 & 6,7 & 6,5 & 6,2 \\
\hline Прибуток, млн. грн. & 0,9 & 2,3 & 2,5 & 2,5 & 2,6 & 3,9 & 4,1 & 4,4 \\
\hline Рентабельність, \% & 32,4 & 50,6 & 55,5 & 53,9 & 60,4 & 57,5 & 62,6 & 70,7 \\
\hline $\begin{array}{l}\text { Окупність капітало- } \\
\text { вкладень, років }\end{array}$ & 6,7 & 5,3 & 4,8 & 5,2 & 2,8 & 5,3 & 4,1 & 3,0 \\
\hline
\end{tabular}

Проте, окрім складності технічних рішень, в проектах багатоповерхових тваринницьких будівель $є$ вельми істотний недолік - тварини в них будуть позбавлені прогулянок, необхідних для нормальної фізіологічної діяльності їх організму i продуктивності, що стримує проектування і будівництво багатоповерхових будівель для утримання в них великої рогатої худоби молочного напрямку.

Запроектовані багатоповерхові тваринницькі будівлі, які вже і діють, призначені в основному для виробництва м'яса і яєць. При цьому не вирішується питання отримання життєздатного здорового потомства.

При розробці проектів багатоповерхових корівників врахована ефективність об'ємнопланувальних вирішень будівель, конструктивних схем, механізація виробничих процесів і утримання тварин, що забезпечують функціональну і фізіологічну діяльність тварин.

При виборі оптимальних систем машин для основних потокових технологічних ліній всі виробничі процеси для боксового утримання худоби, як одного 3 найбільш індустріального способу, що вирішувалися з урахуванням застосування машин, можуть бути використання у таких будівлях. В цьому відношенні були визначені наступні механізми: для транспортування і роздачі кормів стрічкові транспортери; для доїння корів установки типу УДЕ-8 «Ялинка»; для прибирання гною з секцій усередині будівлі скреперна установка УС-1,5 типу «дельта-скрепер», а з поперечних каналів установка УС-1,0; для транспортування гною в гноєсховища насоси НЖН-200.

Багатоповерхове будівництво дозволяє здійснювати об'ємно-планувальну структуру будівлі на основі двох методів; горизонтального i вертикального блокування. Менше витрачається залізобетонних конструкцій на будівлі шириною 42 м 3 сіткою колон $6 \times 10,5$ м (зрозуміло, при оптимальній технології).

При вертикальному блокуванні більшою мірою вдається використовувати принцип гравітації при транспортуванні молока, кормів і гною. Враховуючи, що промислова технологія виробництва молока передбачає в структурі стада 100\% корів (67\% дійних, 13 - сухостійних і 12 - глибоко тільних, новотільних та 8\% вибракуваних), доцільно проектувати трьохповерхові 
будівлі з розміщенням дійного стада на двох верхніх поверхах у кількості 800 корів, а пологове відділення з профілакторієм нетелями та телятами до 4 місячного віку - на першому.

На третьому поверсі розміщено 400 дійних корів. Технологічні процеси подібні до корів другого поверху, з вигульно-годівельними майданчиками.

Так, на першому поверсі передбачені секції для утримання корів передпологова (1) на 78 місць (рис. 1).
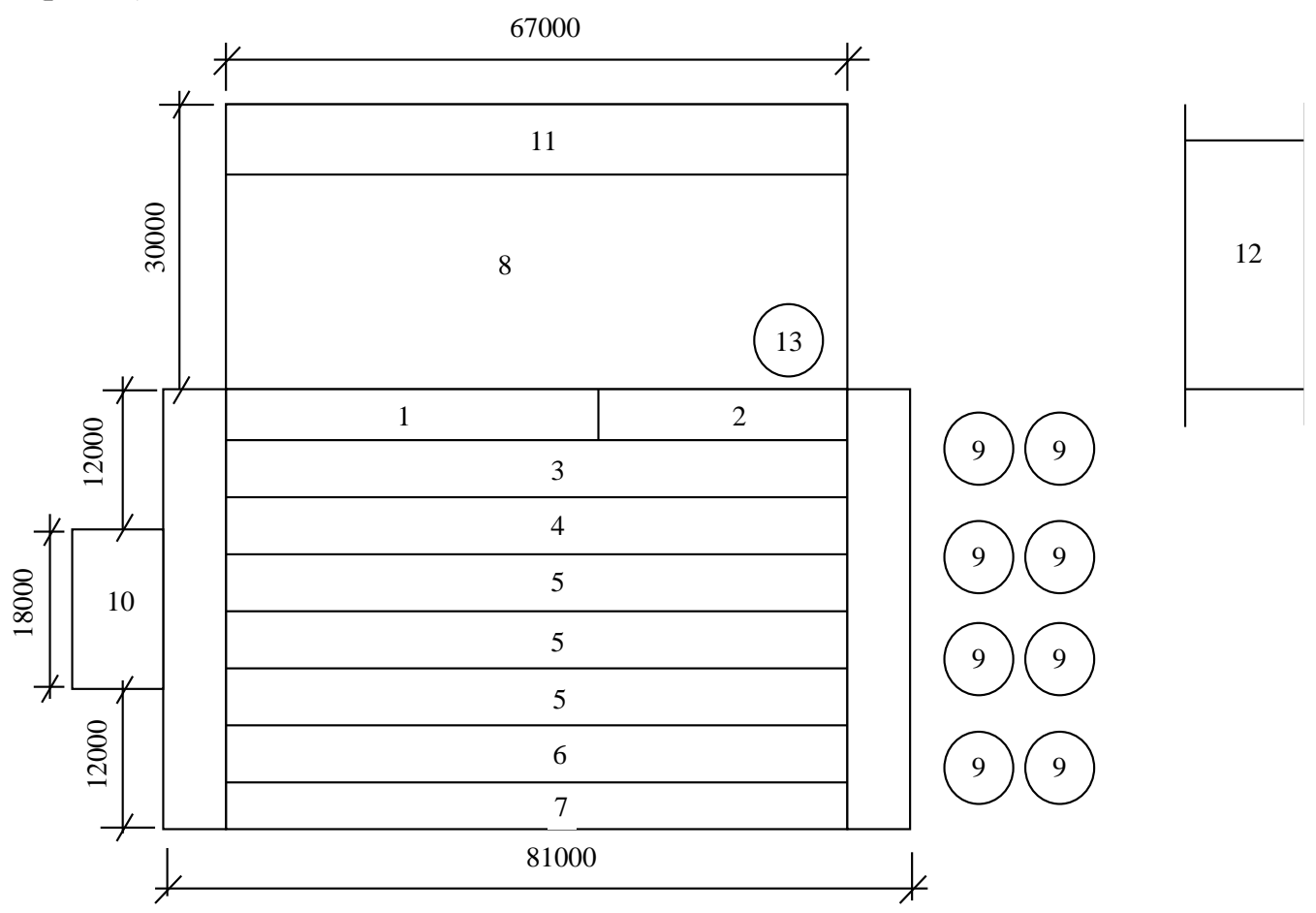

Рис. 1. Схема плану розміщення пологового відділення, сухостійних корів, нетелів та телят до 4-місячного віку (перший поверх)

1-передпологова секція (78 місиь); 2-денники для отелів (12 штук); 3-післяпологова секиія (62 місия); 4-профілакторій (72 клітки); 5-телята до 4 місячного віку (210 голів); 6-сухостійні корови (144 місия); 7-нетелі (104 місия); 8-вигульно-годівельні майданчики; 9-сінажсні башти; 10адміністративні приміщення; 11-годівельний стіл; 12-крите гноєсховище; 13-насосна станція.

За основу об'ємно-планувального вирішення типового поверху багатоповерхової будівлі прийнята технологічна схема корівника на 400 голів безприв'язно-боксового утримання, яка широко використовується для масового будівництва одноповерхових корівників, яка відповідає наступним вимогам: оптимальна ширина приміщення 42 м (2х21); найбільш ефективна схема секцій 3 повздовжнім розташуванням в них боксів (по 50 в кожній секції), де годівля корів здійснюється за допомогою двосторонніх стрічкових транспортерів; доїльно-молочний блок розташований в торці приміщення; видалення гною проводиться системою скреперних установок. При будівництві багатоповерхових корівників в основному використовуються індустріальні вироби промислової номенклатури.

Зрозуміло, будувати корівник заввишки більше трьох поверхів можна тільки передбачаючи підйомні пристрої (ліфти) і установки активного моціону на кожному 3 них. Виключено дороге обладнання для транспортування корів можливе при обладнанні вигульних майданчиків на кожному поверсі.

Утримання корів у передпологовій секції безприв’язне комбібоксове. У секції № 2 обладнано денники (12 штук), утримання безприв'язне на підстилці. У післяпологовій секції корів утримують на прив'язі, доїння у відро. Сухостійних корів і нетелів утримують безприв'язно у комбібоксах. Телят у профілакторіях розміщують у індивідуальних клітках (72 голови). Телята у віці до 4 місяців утримуються у групових клітках по 15 голів у 14 клітках (210 голів).

Вигульно-годівельні майданчики розміром 30х67 м забезпечують вільний рух корів і телят по 5-8 годин на добу, що компенсує природне освітлення на першому поверсі.

Корми доставляються пневмотранспортом до стаціонарного кормороздавача кормів коровам, нетелям та телятам із сінажних башт. Концентровані корми - подаються із бункерів тросошайбовим транспортером у самогодівниці. Сіно тваринам згодовують на вигульних 
майданчиках. Зелені корми доставляють із полів мобільними кормороздавачами і роздають на годівельний стіл - добовий раціон за один раз.

Видалення гною - дельта-скрепером на похилий транспортер, а ним за межі приміщення.

На рисунку 2 представлена схема плану розміщення 400 дійних корів (другий поверх). Корови утримуються безприв'язно у комбібоксах 3 видаленням гною дельта-скрепером. Роздача сінажу із башт на стаціонарний транспортер. Доїння корів групами по 50 голів, які направляються у доїльно-молочний блок «Ялинка». Після доїння кожна із восьми груп повертається у секцію приміщення, або на вигульно-годівельний майданчик.

При розробці проектних пропозицій по багатоповерхових корівниках доцільно передбачати можливість використання рельєфу місцевості, що має ухил до 10-18\%. У таких випадках будівлі зводяться з прибудовою терасних вигулів на схилах майданчика, сполучених з кожним поверхом корівника перехідними естакадами на одному рівні із стійловими приміщеннями.

Запропонована схема обладнання схилу для терас вигульно-годівельного майданчика представляє $10 \%$ схил місцевості. Так, на верхній терасі розміщено вигульно-годівельні майданчики для дійних корів третього поверху, які направляють по галереї руху (7). На другій терасі розміщені вигульно-годівельні майданчики для другого поверху дійних корів (3). 3 другої сторони будівлі - представлені вигульно-годівельні майданчики (2) для тварин першого поверху.

У звичайних умовах будівництва проектуються пандуси з ухилом не більше $5 \%$ або ліфти. При цьому на кожному поверсі вмонтовується установка для активного моціону тварин. Спуск $\mathrm{i}$ підйом тварин проводиться один раз в рік (у пологове відділення і назад або при вибракуванні).

3 урахуванням прогнозів концентрація поголів'я тварин на фермах в перспективі збільшуватиметься. Так, за даними норм технологічного проектування, комплекси повинні бути на 10-15 тис. голів великої рогатої худоби.

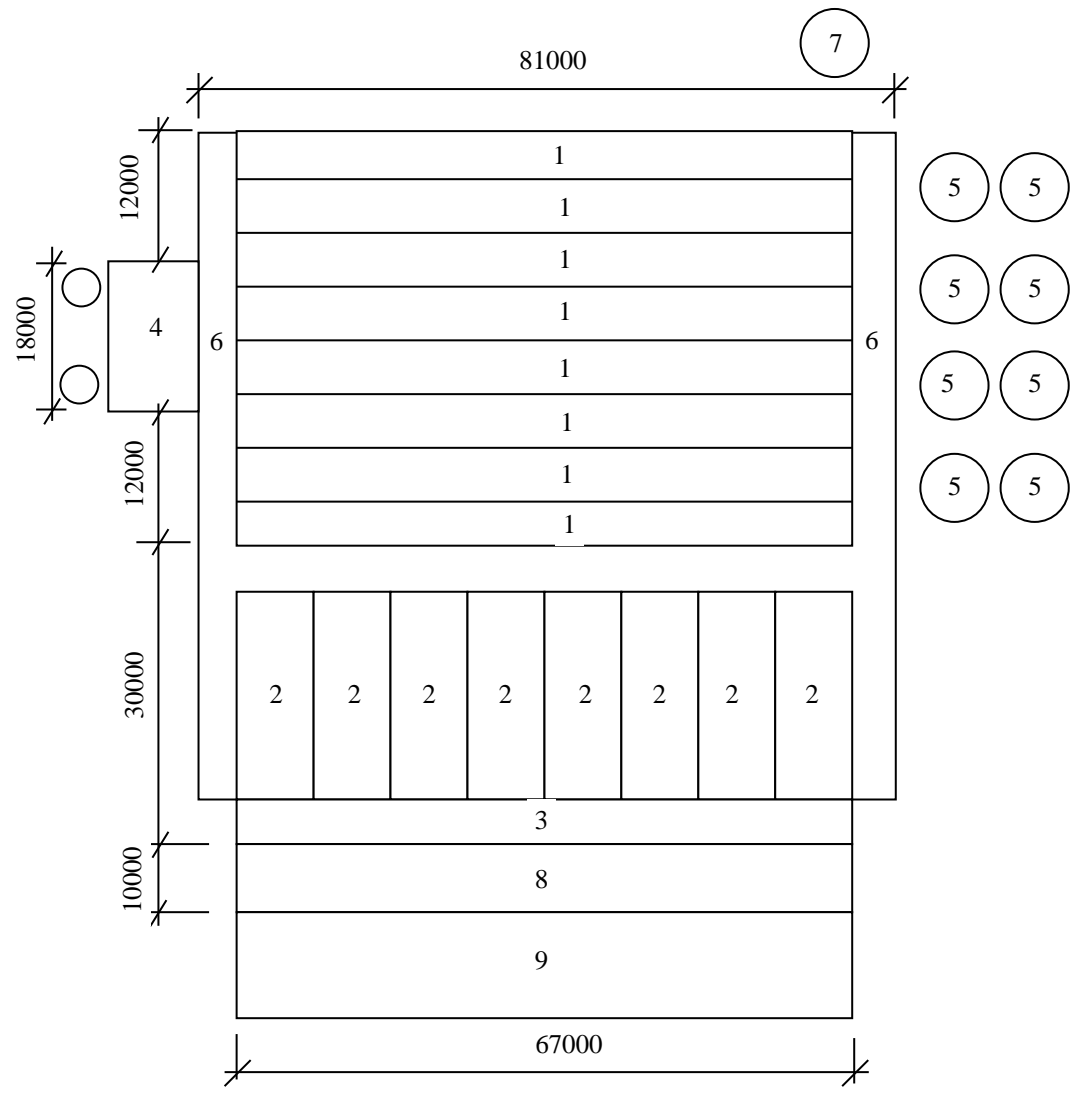

Рис. 2. Схема плану розміщення 400 дійних корів (другий поверх)

1-технологічна група на 50 корів; 2-вигульні майданчики; 3-годівельний стіл; 4-доӥльна установка «Ялинка»; 5-сінажні башти; 6-скотопрогіна галерея; 7-насосна станція; 8-підпірний схил; 9-вигульно-годівельні майданчики третього поверху; 10-бункери для конщентрованих кормів.

Виробничі сільськогосподарські будівлі, що будуються із збірного залізобетонну, споруди мають термін служби понад 100 років. Це означає, що вони експлуатуватимуться 
повністю у даному 21 столітті. Тому, дуже важливо вирішувати питання типології будівель в технологічному, об’ємно-планувальному, конструктивному плані та 3 врахуванням енергоощадного виробництва молока.

Правильна оцінка всіх чинників при проектуванні технології і об’ємно-планувальної структури тваринницьких комплексів забезпечить нормальне функціонування їх на далеку перспективу.

Основою багатоповерхових будівель для виробництва молока майбутнього можуть бути нині проектовані рішення багатоповерхові будівлі для утримання великої рогатої худоби молочного напряму за найбільш енергоощадних технологій та раціонального їх розміщення.

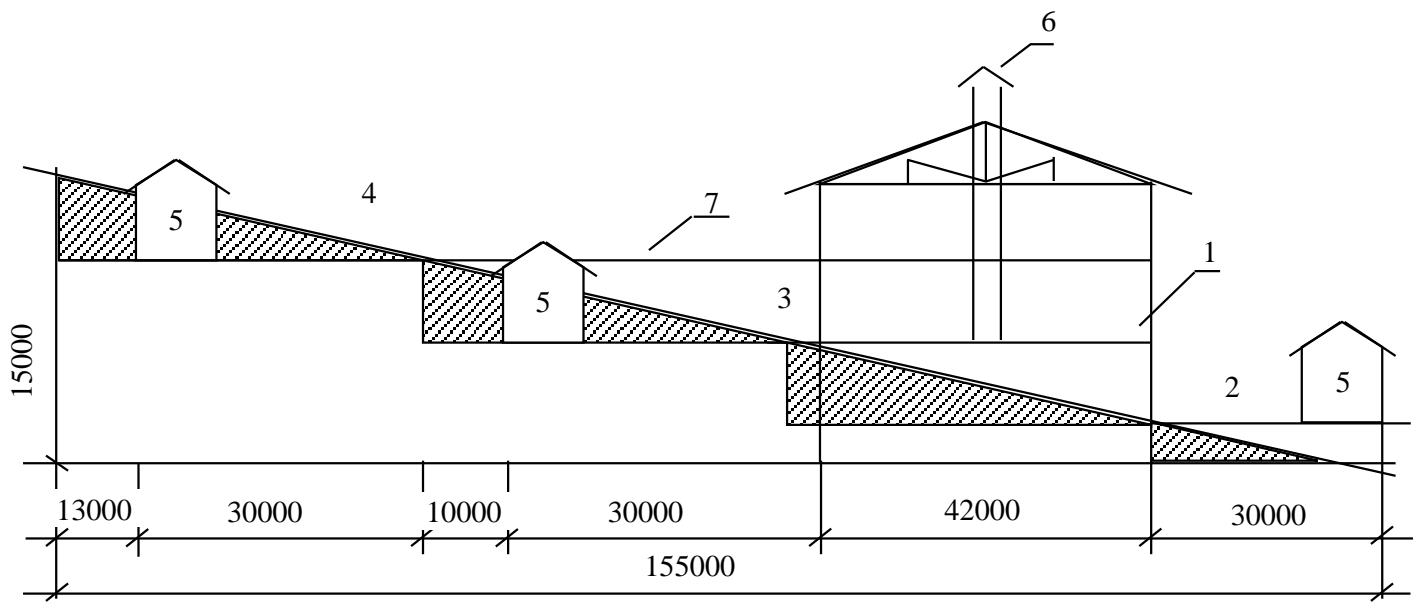

Рис. 3. Схема обладнання схилу для терасних вигульно-годівельних майданчиків

1-трьохповерхова твариннищька будівля; 2-вигульно-годівельний майданчик для першого поверху; 3 вигульно-годівельні майданчики для другого поверху; 4-вигульно-годівельні майданчики для третього поверху; 5-навіс над годівельним столом; 6-вентилящійні шахти для першого, другого та третього поверхів; 7-галерея для руху корів на вигульно-годівельні майданчики.

До молочних комплексів приміських зон представляються підвищені вимоги. Виходячи із цього за будівництва багатоповерхових будівель для утримання молочної худоби в приміських зонах великих індустріальних центрів необхідно покращувати архітектурнохудожню виразність їх зовнішнього вигляду. В умовах щільної забудови і густої мережі транспортних магістралей багатоповерхові тваринницькі будівлі повинні мати строгий, привабливий вигляд, властивий архітектурі промислових підприємств і органічно вписуватися в навколишній ландшафт.

Не менш важливе завдання - оформлення виробничих приміщень, що забезпечують комфортабельні умови роботи обслуговуючого персоналу, що сприяє підвищенню продуктивності праці.

Споруда крупних об'ємних будівель на одному майданчику дозволяє ввести ефективнішу організацію будівельно-монтажних робіт, що зрештою прискорює їх введення в експлуатацію та зменшує затрати на одне скотомісце.

Такі підходи до молочних підприємств мають значну енергоощадну основу і $\epsilon$ перспективними та потребують детальніших наукових досліджень, як 3 теоретичного обгрунтування, так і практичної доцільності використання земельних запасів.

Висновки. 1. Планування підприємств 3 виробництва молока із забудовую будівлі розміром 42х81 м у трьохповерховому варіанті із використанням земельного ландшафту 3 ухилом $12-18 \%$ на 1200 корів забезпечує витрати на одну голову $20,42 \mathrm{~m}^{2}$, площу будівлі $-8,5$ $\mathrm{M}^{2}$, виробництво молока на одного основного робітника 187,5 т за рік та 3 одного гектара забудови - 2449 т при рівні рентабельності 70,74\%.

2. Серед підприємств на 800 корів перевагу можна віддати зблокованій будівлі 21х120 м, у кожній будівлі утримання 400 корів за площі приміщення на одну голову $6,3 \mathrm{~m}^{2}$, утримання корів, видалення гною бульдозером та рівнем рентабельності - 60,4\%.

3. Зблоковані корівники на 200 корів по довжині на 400 корів розміром $72 \times 60$ м 3 безприв'язним боксовим утриманням, доїнням у відро, стаціонарною роздачею кормів та видаленням гною дельта-скрепером уступає всім іншим варіантам за площею будівлі на одну 
корову $\left(10,8\right.$ м $\left.^{2}\right)$, прибутком (862,4 тис. грн.), рівнем рентабельності $(32,38 \%)$ та окупністю капіталовкладень $(6,7$ роки).

4. Пропонується з метою раціонального використання непридатних земель для ведення рослинництва розробити багатоповерхові корівники 3 терасами вигульних майданчиків та утримувати корів безприв'язі у боксах, доїнням на «Ялинці», стаціонарною роздачею кормів, видаленням гною дельта-скрепером.

\section{ЛIТЕРАТУРА}

1. Відомчі норми технологічного проектування : Скотарські підприємства (комплекси, ферми, малі ферми), ВНТП АПК 01.05. - К. : Міністерство аграрної політики України, 2005. - 110 с.

2. ДБН В.2.2 - 1 - 95 Державні будівельні норми України. Будинки і споруди. Будівлі і споруди для тваринництва.

3. Карелин А.И. Зоогигиенические основы проектирования, строительства и эксплуатации животноводческих объектов / А.И. Карелин, Б.Л. Маравин. - М.: Россельхозиздат, 1987. - 271 с.

4. Польовий Л. В. Інноваційні підходи до направленого вирощування теличок і нетелей при реконструкції тваринницьких будівель / Л. В. Польовий, О. Л. Польова, Р. Л. Варпіховський, А. І. Глух. - Науковий вісник Львівського національного університету ветеринарної медицини та біотехнологій ім. С. З. Гжицького. Львів. - 2010. - Том 12, № 4 (46). - С. 171-176.

5. Польовий Л. В. Обладнання приміщень для утримання нетелів у стійловий період / Л. В. Польовий, Р. Л. Варпіховський // Вісник Державного вищого навчального закладу «Державний агроекологічний університет». № 1, 2007 : Науково-теоретичний збірник. - Житомир : ДАУ, 2007. - С. 143-146.

6. Польовий Л. В. Оцінка виробничих площ у приміщеннях при моделюванні технології вирощування ремонтного молодняку великої рогатої худоби / Л. В. Польовий, В. В. Костик // Збірник наукових праць Вінницького державного аграрного університету : Матеріали науково-практичної конференції «Проблеми становлення галузі тваринництва в сучасних умовах» 23-25 травня 2005 року. - Вінниця: ВДАУ, 2005. - Вип. 22. - Ч. 2. - С. 54-61 